\title{
LOSING CONTROL
}

Stephen D. King is HSBC's Group Chief Economist and the bank's global head of economics and asset allocation research. The author of a weekly column for the London Independent since 2001, he is also a member of The Economist's 'By Invitation' panel of experts, the Financial Times Economists' Forum and the UK Government's Asia Taskforce. In his spare time, he plays the piano. 



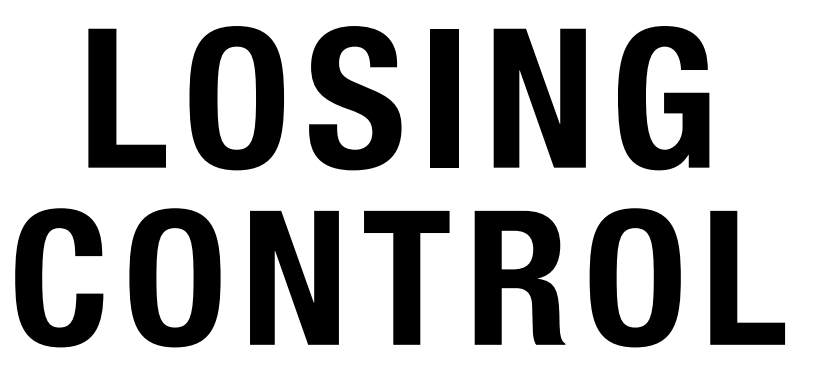

\title{
THE EMERGING THREATS TO WESTERN PROSPERITY
}

\author{
STEPHEN D. KING
}




\section{Copyright @ 2010 Stephen D. King}

First printed in paperback 2011

The right of Stephen D. King to be identified as author of this work has been asserted by him in accordance with the Copyright, Designs and Patents Act 1988.

All rights reserved. This book may not be reproduced in whole or in part, in any form (beyond that copying permitted by Sections 107 and 108 of the U.S. Copyright Law and except by reviewers for the public press) without written permission from the publishers.

For information about this and other Yale University Press publications, please contact: U.S. Office: sales.press@yale.edu yalepress.yale.edu Europe Office: sales@yaleup.co.uk www.yalebooks.co.uk

Set in Minion by IDSUK (DataConnection) Ltd Printed in Great Britain by Hobbs the Printers Ltd, Totton, Hampshire

Library of Congress Cataloging-in-Publication Data

King, Stephen D., 1963-

Losing control : the emerging threats to western prosperity / Stephen D. King. p. $\mathrm{cm}$.

ISBN 978-0-300-15433-7 (cl : alk. paper) 1. Western countries-Economic conditions-21st century. 2. Western countries-Economic policy. 3. Developing countries-Economic policy. I.

Title.

HC59.3.K56 2010

$330.9-\mathrm{dc} 22$

ISBN 978-0-300-17087-0 (pbk)

A catalogue record for this book is available from the British Library. 